\title{
Immunological studies in a case of T-cell leukaemia
}

\author{
G. STATHOPOUlOS, M. PAPAMICHAIL, P. SHELDON, D. CATOVSKY, \\ A. J. S. DAVIES, E. J. HOLBOROW, AND EVE WILTSHAW \\ From the Department of Immunobiology, Chester Beatty Research Institute, London, \\ the MRC Rheumatism Unit, Canadian Red Cross Memorial Hospital, Taplow, \\ the Department of Chemotherapy, Royal Marsden Hospital, London, and the MRC Leukaemia Unit, \\ Royal Postgraduate Medical School, London
}

SYNOPSIS The blood lymphocytes from a case of prolymphocytic leukaemia were subjected to a battery of different tests in order to establish as certainly as possible their T or B cell type of origin. The results of the tests for surface markers indicated the T-cell origin of the leukaemic cells in this patient, and this provided a good opportunity to determine the participation of $\mathrm{T}$ cells in the various tests proposed for measuring human lymphocyte function.

Lymphocytes in both mice and man have been characterized as thymus (T) and bone marrow (B) derived on the basis of surface properties such as immunoglobulin staining (Papamichail, Brown, and Holborow, 1971; Froland, Natvig, and Berdal, 1971), $\mathrm{C}_{3}$ receptors (Bianco, Patrick, and Nussenzweig, 1970), Fc receptors (Dickler and Kunkel, 1972), or the formation of rosettes with sheep red blood cells (Lay, Mendes, Bianco, and Nussenzweig, 1971; Jondal, Holm, and Wigzell, 1972; Papamichail, Keith, Currey, and Holborow, 1972). It has also been found, particularly in rodents, that the two kinds of lymphocytes can respond differently to mitogens such as PPD and lipopolysaccharide (B cells) (Sultzer and Nilsson, 1972; Greaves and Janossy, 1972), phytohaemagglutinin (PHA), Concanavalin A (Con A) (T cells), and pokeweed mitogen (PWM) (both $T$ and $B$ cells) (Greaves and Janossy, 1972).

Studies of human lymphocytes in chronic lymphocytic leukaemia, applying a limited number of these criteria, have suggested the disease to be predominantly of B cells (Papamichail et al, 1971; Preud'homme and Seligman, 1972; Grey, Rabellino, and Pirofsky,1971). Prolymphocytic leukaemia in the majority of the cases studied is shown likewise to have B-cell characteristics. However, in one case which has already been reported in a preliminary manner (Catovsky, Galetto, Okos, Galton, Wiltshaw, and Stathopoulos, 1973), there were indications that the cells were of T-cell origin. In the present Received for publication 5 August 1974. investigation a battery of different tests for lymphocyte markers has been used in order to establish as certainly as possible the T-cell origin of the leukaemic cells in this patient.

\section{Clinical Summary}

A woman, R.R., aged $58 \mathrm{yr}$, presented to the Brompton Chest Hospital with fcver, weakness, and dyspnoea of two months' duration. Examination revealed lymphadenopathy involving the neck, axillae, and inguinal regions. There was gross splenic enlargement. There was also evidence of chest infection and situs inversus.

Investigations were as follows: $\mathrm{Hb} 82 \%$; white cell count $150000 / \mathrm{mm}^{3}$ ( $97 \%$ lymphocytes, platelets $95000 / \mathrm{mm}^{3}$ ). Blood and marrow smears showed some abnormally large cells with prominent nucleoli.

A diagnosis of leukaemia of prolymphocytic type was made and prednisone $60 \mathrm{mg}$ daily was prescribed, subsequently reduced and discontinued after two months.

At this stage the patient was transferred to the Royal Marsden Hospital. Investigations were as follows: haemoglobin (Hb) $10.9 \mathrm{~g} 100 \mathrm{ml}$; platelets $135000 / \mathrm{mm}^{3}$; white cell count, $513000 / \mathrm{mm}^{3}$ (96\% cells were of prolymphocytic type).

A chest radiograph showed a right-sided pleural effusion.

Cytotoxic therapy was commenced as follows: (1) cyclophosphamide $500 \mathrm{mg}$ intravenously once; 
(2) vincristine $2 \mathrm{mg}$ intravenously repeated after one week; (3) asparaginase 10000 units daily for 14 days.

There was slight regression in the size of lymph nodes and spleen. The pleural effusion receded. However the white cell count remained essentially unchanged and two weeks later the patient collapsed and died. Permission for necropsy was not given.

\section{Methods}

LYMPHOCYTE SEPARATION

Ten $\mathrm{ml}$ heparinized venous blood was added to an equal volume of Ficoll-Triosil and centrifuged at $2000 \mathrm{rpm}$ for 20 minutes. The cells at the interphase were then washed three times in medium 199.

SPONTANEOUS ROSETTE-FORMING CELLS (SRFC) This test was performed by techniques which differed slightly between the Chester Beatty Institute and Taplow. The details of the test as performed at the latter institution are given in parentheses.

Sheep red blood cells were washed three times in normal saline and made up to a dilution of $0.5 \%$ in medium 199 (normal saline). Of this cell suspension $0.25 \mathrm{ml}(0.5 \mathrm{ml})$ was mixed in a plastic tube with $0.25 \mathrm{ml}(0.6 \mathrm{ml})$ of the lymphoid cell suspension containing $4 \times 10^{6}$ cells $/ \mathrm{ml}\left(3 \times 10^{6}\right.$ cells $\left./ \mathrm{ml}\right)$. Fetal calf serum, $0.05 \mathrm{ml}$, ie, $10 \%$, was added and the tube incubated for five minutes at $37^{\circ} \mathrm{C}(10$ minutes at room temperature), centrifuged at $1000 \mathrm{rpm}$ for five minutes, and then incubated at $4^{\circ} \mathrm{C}$ for one hour (and 24 hours).

The cells were resuspended gently by hand (Matburn rotator) and $0.1 \mathrm{ml}$ of a $10 \%$ dilution of glutaraldehyde in medium 199 was added to each tube (not done). The cells were left for 15 to 30 minutes at room temperature (not done). Twentyfive $\mu$ l of the cell suspension ( 1 drop) was stained by the addition of $25 \mu 10.22 \%$ methylene blue (not done) and examined under a coverslip. At least 200 cells were counted by light microscopy with a $\times 40$ objective and $\times 10$ eyepiece.

A rosette was defined as one lymphocyte with at least three sheep erythrocytes attached. Cytocentrifuge preparations of the SRFC were made and stained with Giemsa.

\section{Spontaneous rosette inhibition tests}

1 Human anti-T cell-specific serum obtained from a patient with a monoclonal IgM light chain cold agglutinin - anti-i (Deuch), kindly supplied by Dr B. Thomas, was used at a dilution of 1:100.

Leukaemic cells were incubated with the above antiserum at $4^{\circ} \mathrm{C}$ for one hour. They were then washed twice and their ability to form spontaneous rosettes was tested as described.
2 Leukaemic cells were incubated with (a) guinea pig kidney, (b) ox red blood cells, (c) antihuman whole immunoglobulin or antihuman immunoglobulin $G$, both at $1: 5$ and $1: 20$ dilution. The leukaemic cells were then washed thrice and the spontaneous rosette test was performed.

COMPLEMENT ROSETTE FORMATION (EAC
ROSETTES)

Ox red blood cells (E) were thrice washed in phosphate-buffered saline (PBS), $\mathrm{pH} 7 \cdot 4$, and a $1 \%$ suspension was made. To $1 \mathrm{ml}$ of this suspension an equal volume of IgM rabbit anti-ox erythrocyte serum (A), diluted 1:40 in PBS was added, and incubated for 30 minutes at $37^{\circ} \mathrm{C}$. The antibodycoated cells (EA) were then again thrice washed in PBS, and $1 \mathrm{ml}$ of a $1 \%$ suspension was incubated at $37^{\circ} \mathrm{C}$ for 30 minutes with an equal volume of fresh human serum diluted 1:20 in PBS as a source of $C_{3}$ (C). The complement-treated cells (EAC) were then washed thrice in PBS and re-constituted to a $1 \%$ suspension.

Lymphocytes, $1-2 \times 10^{6}$, were added to $0.25 \mathrm{ml}$ $1 \% \mathrm{EAC}$, centrifuged at $1000 \mathrm{rpm}$ for five minutes, and incubated at $37^{\circ} \mathrm{C}$ for 30 minutes. The cells were then re-suspended gently by hand, and one drop of suspension examined under a coverslip. A\& EAC rosette was defined as one lymphocyte with a least 3 EAC attached.

\section{Mitogen responsiveness}

The following mitogens were used: phytohaemagglutinin (PHA), concanavalin A (Con A), pokeweed mitogen (PWM), purified protein derivative (PPD), endotoxin, sodium periodate $\left(\mathrm{NalO}_{4}\right)$.

\section{Technique}

Tubes containing $0.5 \times 10^{6}$ cells in $0.55 \mathrm{ml}$ medium 199 including $0.05 \mathrm{ml}$ fetal calf serum were set up, one having $25 \mu \mathrm{l}$ normal saline added, as control, and two having mitogen. They were incubated in an atmosphere of $7 \%$ carbon dioxide, $13 \%$ oxygen, and $80 \%$ nitrogen for two to six days at $37^{\circ} \mathrm{C}$. At various times from day 1 to 5 inclusive tritiated thymidine $25 \mu \mathrm{l}$ of $10 \%$ solution, specific activity $22 \mu \mathrm{Ci} / \mathrm{mmol}$, was added to each set of three tubes and six or 16 hours later the cells were harvested onto filter discs, two per tube. The filter discs were washed first with $10 \%$ trichloroacetic acid, then with $3 \%$ perchloric acid followed by methanol twice and ether once. Radioactivity was counted in a liquid scintillation spectrophotometer. The results were expressed as counts per minute per $\mathrm{ml}$ of cell suspension.

Each of the means given represents two samples for controls and four for the stimulated cells. The 
deviation of these numbers among each other was less than $25 \%$. Phytohaemagglutinin-stimulated cells were also examined morphologically on cytocentrifuged preparations stained with Giemsa. Autoradiographs of these specimens were made by the dipping emulsion technique with two weeks' exposure.

\section{Sodium Periodate Stimulation Technique}

This was performed according to the method of Parker, O'Brien, Steiner, and Paolilli (1973). Briefly, four samples of lymphocytes each of $5 \times$ $10^{6}$ cells were incubated with phosphate-buffered saline (PBS) free from magnesium and calcium, and with sodium periodate $\left(\mathrm{NalO}_{4}\right)$ at a concentration of $1-3 \times 10^{-3} \mathrm{M}$ for 15 minutes at room temperature. The cells were then washed twice in PBS and resuspended in RPM1 1640 (Bio-Cult Laboratories, Glasgow) with $10 \%$ inactivated fetal calf seum, Hepes buffer IM, L-glutamine (Bio-Cult Labs) plus antibiotics. Plastic tubes each containing $1 \times 10^{6}$ cells $/ \mathrm{ml}$ medium were set up in triplicate and incubated at $37^{\circ} \mathrm{C}$ for 72 hours. ${ }^{14} \mathrm{C}$ Thymidine was then added and six hours later the cells were harvested onto filter discs and processed as described above. The periodic acid Schiff reaction was performed according to Dacie and Lewis (1963).

\section{Immunofluorescent Staining Technique}

DIRECT METHOD

Leukaemic cells, $2-3 \times 10^{6}$, were incubated for $\frac{1}{2} \mathrm{hr}$ at $4^{\circ} \mathrm{C}$ with $0.2 \mathrm{ml}$ of the appropriate fluoresceinconjugated antiserum diluted 1:6. The conjugates used were antiwhole human serum, antihuman IgG, antihuman IgM, antihuman IgA (Wellcome Research Laboratories), and had previously been ultracentrifuged to remove any aggregated material. After incubation the cells were washed three times, mounted in $50 \%$ glycerol, and examined for membrane immunofluorescence by epi-illumination with a Zeiss photomicroscope (HBO 200 light source, interference filter $500 \mathrm{~nm}, 500 \mathrm{~nm}$ reflector, $40 \times$ oil planapochromat objective, $10 \times$ eye piece, barrier filter with cut off below $500 \mathrm{~nm}$.)

\section{INDIRECT METHOD}

Rabbit antihuman whole immunoglobulin, antihuman IgD (Nordic Diagnostics), sheep antihuman IgG and IgM sera (Burroughs Wellcome), and antihuman $F(a b)_{2}$ serum prepared in rabbits by immunization with human $\mathrm{F}(\mathrm{ab})_{2}$ fractions (kindly donated by Dr M. Turner) diluted 1:10 were incubated with $2-3 \times 10^{6}$ cells for 30 minutes. The cells were then washed three times, incubated with fluorescent goat antirabbit or rabbit antisheep serum diluted 1:10 for 30 minutes, washed again and mounted in $50 \%$ glycerol for observation.

Human anti-T-cell-specific serum (for specificity see Thomas, 1973), rabbit antihuman T, and B blast sera (for specificity see Thomas and Phillips, 1973) were kindly supplied by Dr B. Thomas. These were incubated undiluted with the leukaemic cells, as above, and the appropriate fluorescein-conjugated antiserum was then applied.

Human aggregated Cohn fraction II gamma globulin solution $(20 \mathrm{mg} / \mathrm{ml})$ was diluted $1: 4$ in PBS and $0.2 \mathrm{ml}$ incubated with $3 \times 10^{6}$ leukaemic cells for 30 minutes at $4^{\circ} \mathrm{C}$. After washing, the cells were incubated with 1:5 antihuman fluoresceinated IgG (Wellcome Reagents), washed, and mounted.

\section{Electron Microscope Observation}

At the end of the incubation period of the sheep red cell rosette test the cell pellet was fixed in $1 \%$ glutaraldehyde for one hour. Araldite sections were stained with a $2 \%$ aqueous solution of uranyl acetate and lead citrate and examined in an AE1-6 electron microscope at $60 \mathrm{KV}$.

\section{Serum Immunoglobulins}

Routine cellulose acetate electrophoresis of the patients' serum was carried out. Quantitation was performed by the Mancini technique.

\section{Results}

Table I and figure 1 show that the majority of the leukaemic cells formed spontaneous rosettes with sheep cells. The variation between different centres presumably reflects the slightly different techniques employed.

Table I also shows that considerable inhibition of SRFC was obtained by preincubation of the leukaemic cells with antihuman $T$ cell serum. The possibility that the spontaneous rosette formation was due

\begin{tabular}{llll}
\hline & $\begin{array}{l}\text { Chester } \\
\text { Beatty }\end{array}$ & Taplow & $\begin{array}{l}\text { Hammer- } \\
\text { smith }\end{array}$ \\
\hline Untreated leukaemic (a) SRFC & $67 \%$ & $86 \%$ & $75 \%$ \\
$\begin{array}{l}\text { (b) EAC } \\
\text { Pretreated with: }\end{array}$ & - & - & $0 \%$ \\
$\begin{array}{l}\text { Monoclonal IgM anti T serum } \\
\text { Pretreatment with }\end{array}$ & - & $15 \%$ & - \\
$\begin{array}{l}\text { 1 Heterophile absorbents } \\
\text { 2 Antihuman whole Ig }\end{array}$ & - & - & $72 \%$ \\
3 Antihuman IgG & - & - & $76 \%$ \\
\hline
\end{tabular}

Table I Results of spontaneous rosette tests in different centres and effect of preincubating the leukaemic cells with possible inhibitors 


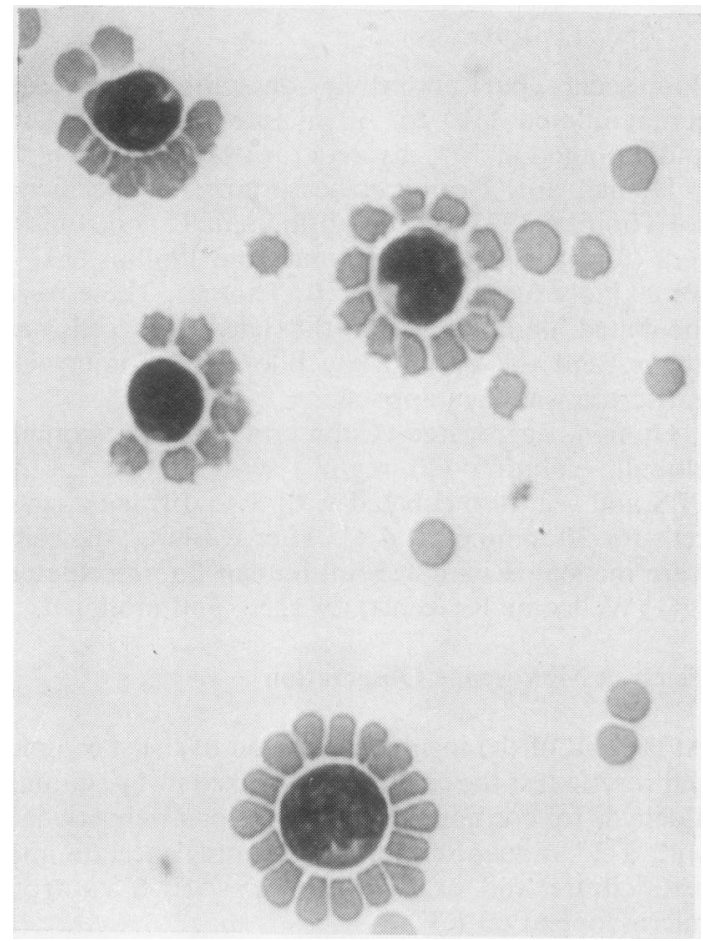

Fig 1 Cytocentrifuge preparation of spontaneous sheep red rosettes formed around the leukaemic cells. Leishman stain. $\times 1500$.

Fig 1

Fig 2 Electron micrograph of a typical leukaemic cell, at the centre of a rosette, showing the attachment areas with the sheep cells. $\times 19500$.

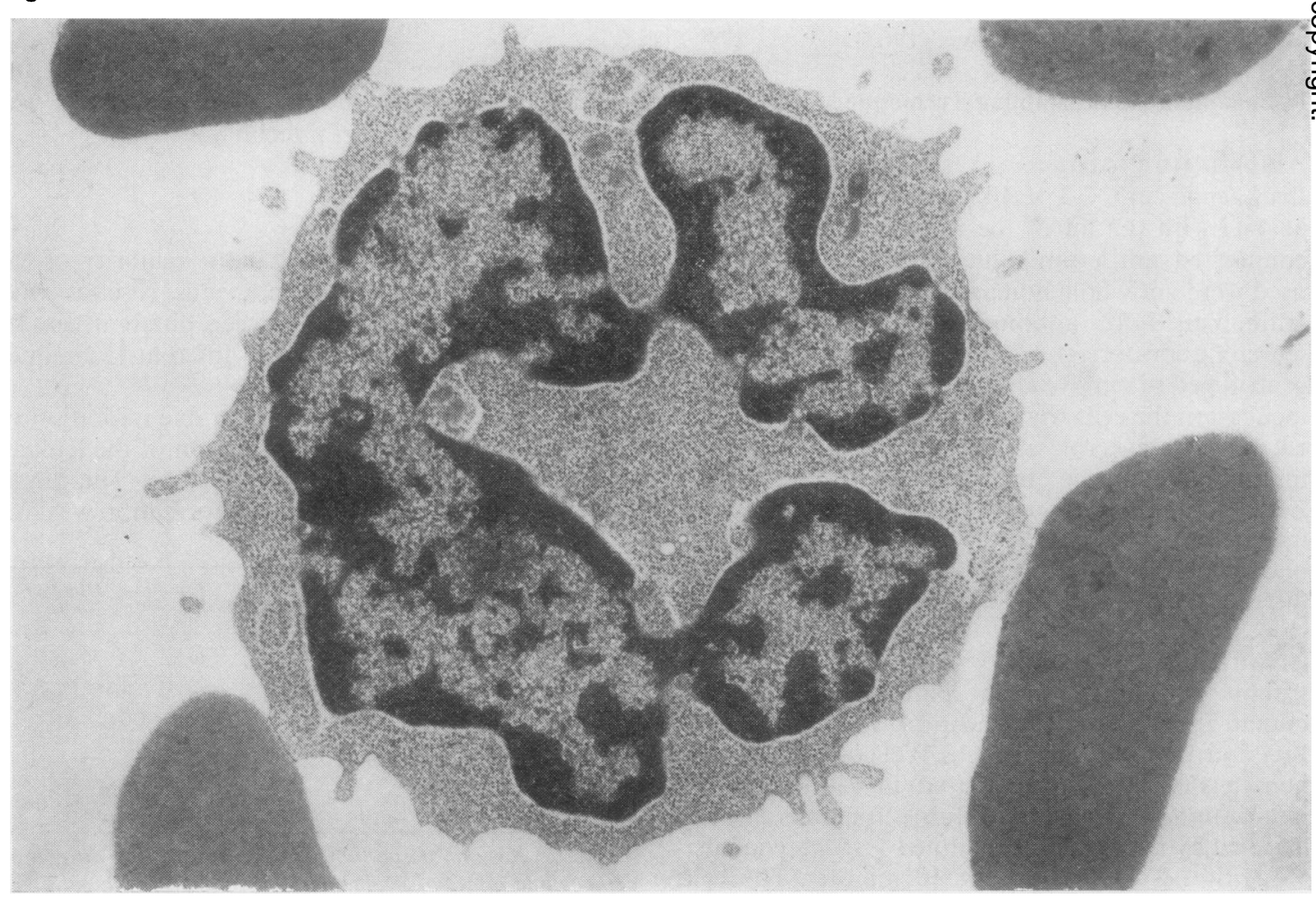

Fig 2 
to the production of heterophile agglutinin on the surface of the cells was excluded by the fact that pre-incubation of the leukaemic cells with heterophile absorbents (guinea pig kidney and ox red cells) did not affect the numbers of rosetting cells.

Electron microscopical examination of the sheep red cell rosettes showed the sheep red cells attached to the lymphocytes by small cytoplasmic projections (fig 2). The leukaemic nature of the cells forming rosettes (prolymphocytes) was easily recognized in many sections because of their bizarre morphology. No cells were found carrying $\mathrm{C}_{3}$ receptors by the complement rosette test.

\section{IMMUNOFLUORESCENCE TESTS}

These showed complete absence of immunoglobulin-bearing cells by both direct and indirect fluorescence (table II). Following incubation with human anti-T cell serum, $92 \%$ of the cells were positively stained with antihuman Ig conjugate. This figure correlates closely with the number of SRFC found (table I).

\begin{tabular}{|c|c|c|}
\hline Antiserum/Conjugate & Direct & Indirect \\
\hline $\left.\begin{array}{l}\text { A-Ig, A-IgG } \\
\text { A-IM, A-IgD } \\
\text { A-IgA }\end{array}\right\}$ & $0 \%$ & $0 \%$ \\
\hline $\begin{array}{l}\text { Agg IgG } \\
\text { A-T cell } \\
\text { A-B cell blast } \\
\text { A-T cell blast }\end{array}$ & & $\begin{array}{l}1 \% \\
92 \%(60 \% \text { in control }) \\
0 \% \\
9 \%\end{array}$ \\
\hline
\end{tabular}

Table II Immunofluorescent staining properties of the leukaemic cells

Anti-T blast sera stained about $9 \%$ of the leukaemic cells while the anti-B blast sera were negative (table III).

\begin{tabular}{llllll}
\hline & \multicolumn{3}{l}{$P H A$} \\
\cline { 2 - 6 } & \multicolumn{2}{l}{ Days } \\
\cline { 2 - 6 } & 1 & 2 & 3 & 4 & 6 \\
\hline $\begin{array}{l}\text { a \% blast-cell transformation } \\
\text { b autoradiography } \\
\text { \% labelled cells }\end{array}$ & - & 85 & 80 & 80 & 75 \\
\hline
\end{tabular}

Table III Blast cell transformation and tritiated thymidine labelling on $P H A$ stimulation

${ }^{1}$ Containing 20 grains/cell.

\section{MITOGEN RESPONSIVENESS}

Morphology

The unstimulated leukaemic lymphocytes were larger than the normal lymphocytes and had prominent nucleoli (fig 3a, b). After the addition of PHA, transformation occurred, and some of the cells were indistinguishable from normal transformed cells (fig 3c, d), but many were about twice the size of normal blasts (fig $3 e, f$ ).

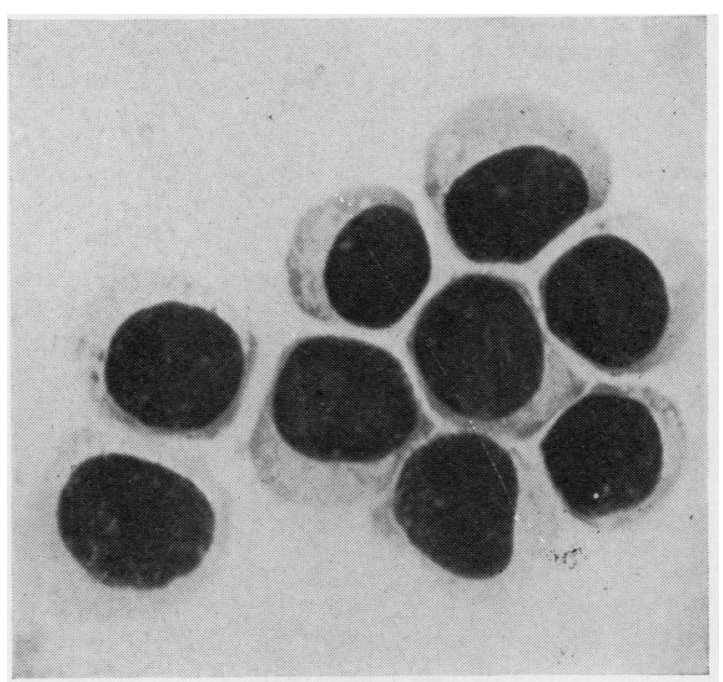

Fig $3 a$

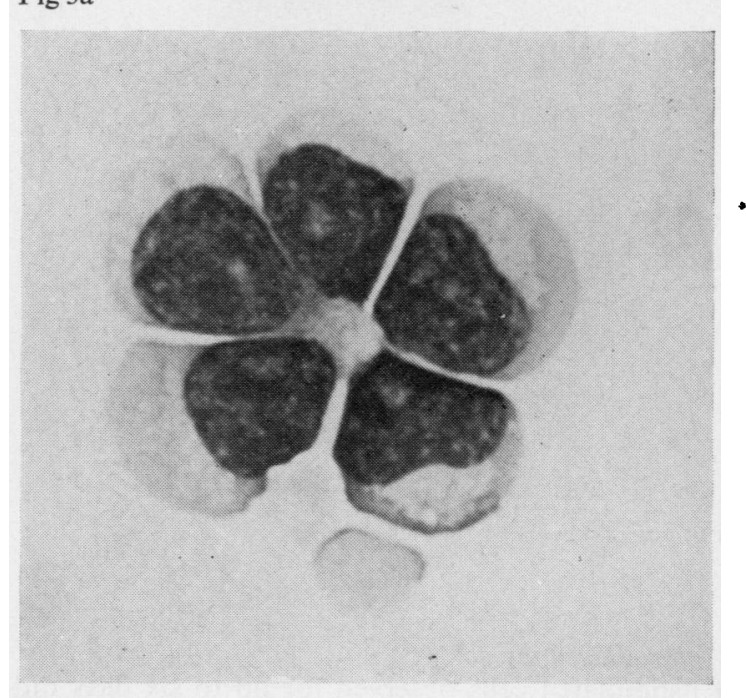

Fig $3 b$

Fig 3 a Normal unstimulated peripheral blood lymphocytes stimulation

b Appearance of unstimulated leukaemic cells c Normal and (d) leukaemic cells after PHA

e, f Some leukaemic blasts are about twice the size of normal blasts. $\times 1400$. 

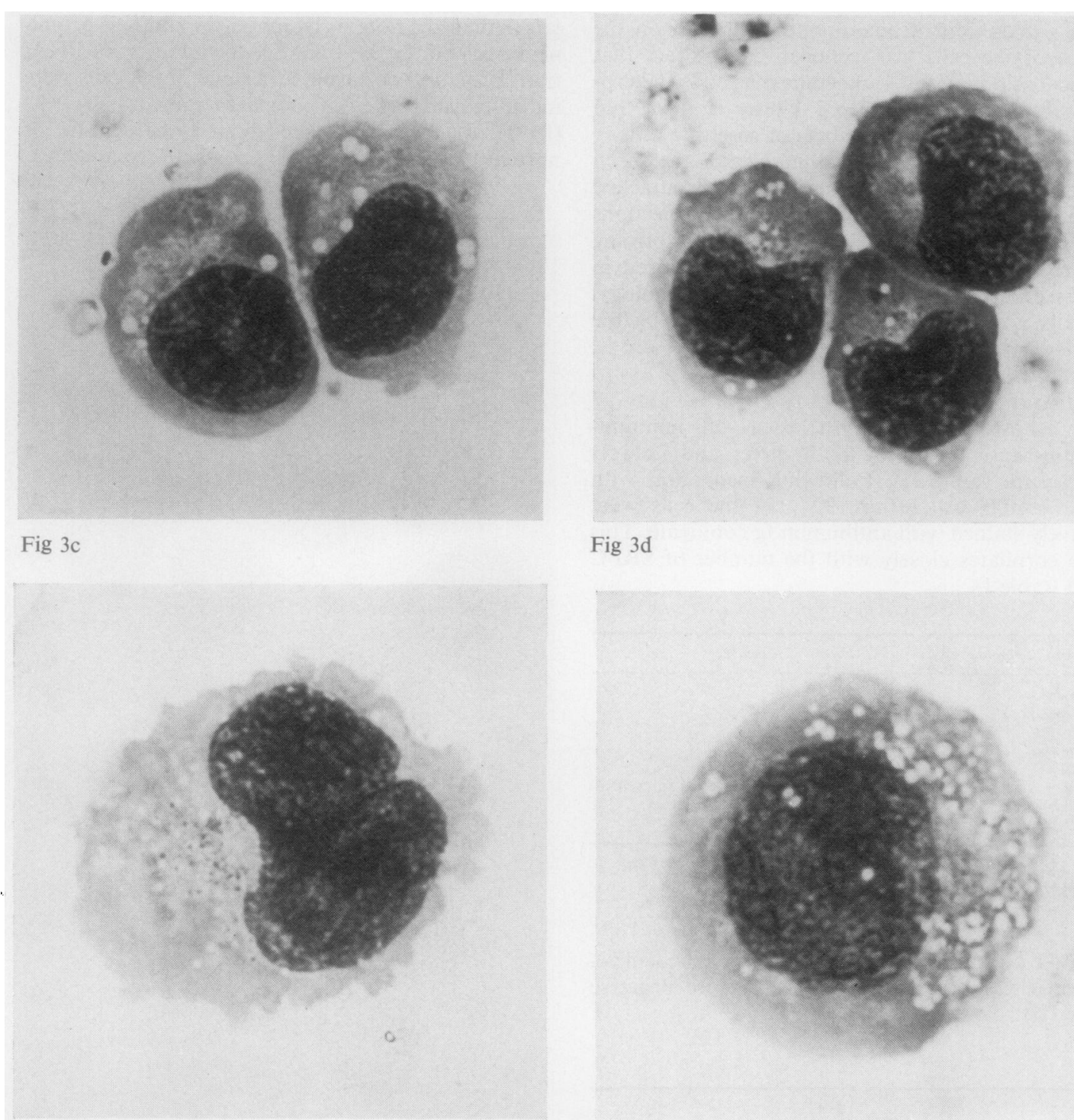

\section{Autoradiography}

Unstimulated cells observed for up to six days did not undergo transformation. Eight-five per cent stimulated cells underwent morphological transformation by day 2 , the peak responses being noted at days 2 and 3 , this finding correlating with the extent of autoradiographic labelling at days 2 and 3.

\section{Uptake of tritiated thymidine}

The peak uptake following PHA occurred on day 3 (fig 4), in agreement with the morphological and autoradiographic findings.

Uptake also occurred after incubation with con A and endotoxin (fig 4) and with PWM but not with PPD in doses of 10 to $100 \mu \mathrm{g}$ (fig 5). Sodium periodate caused increased uptake at $1 \times 10^{-3} \mathrm{M}$, but not at higher concentrations (fig 5).

PAS STAINING

The same proportion ( $30 \%$ ) of unstimulated control 


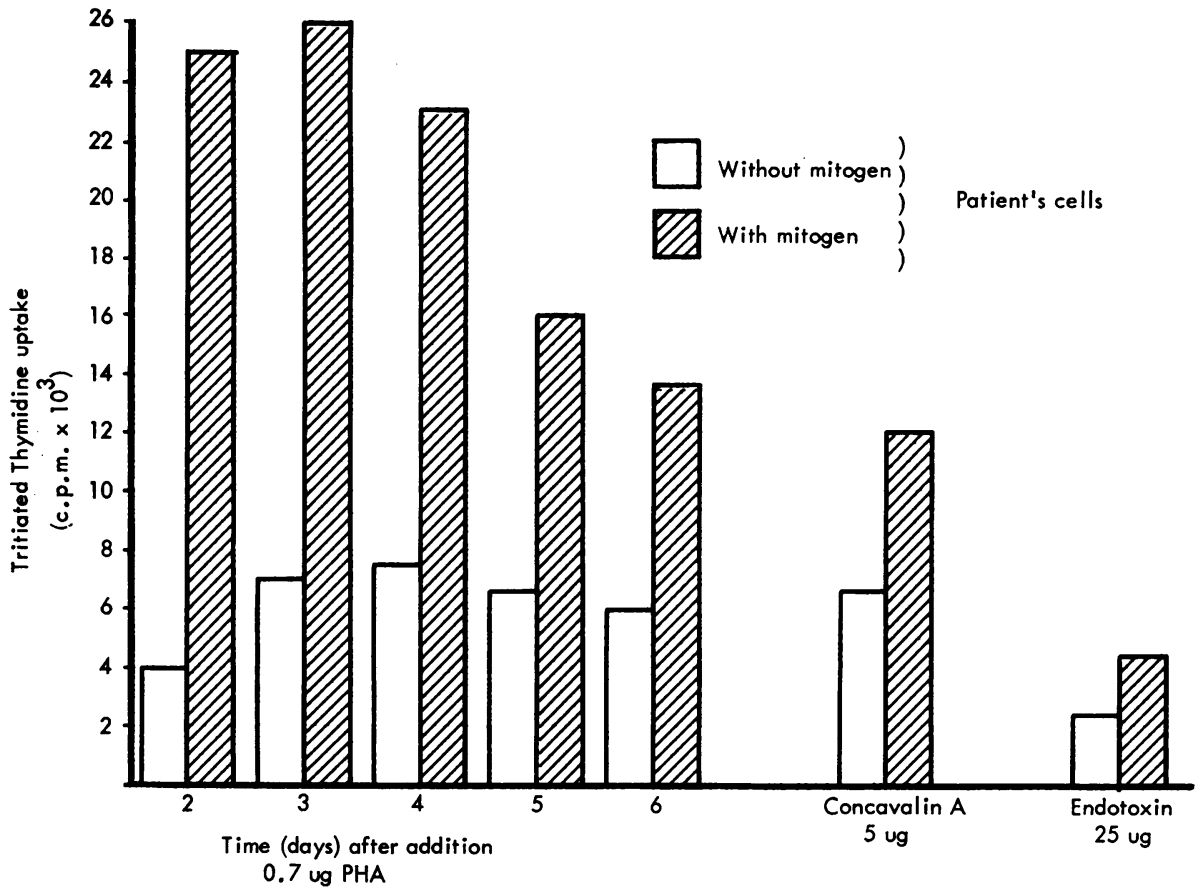

Fig 4 Response to $P H A$, concanavalin $A$, and endotoxin (tritiated thymidine uptake).

and leukaemic cells were positive, but after PHA the proportion of leukaemic cells showing PAS staining was greater (90\% against $55 \%$ ) (fig 6). The PAS staining was attributable to the presence of glycogen, since it was abolished by pretreatment with active though not with boiled diastase.
SERUM IMMUNOGLOBULINS (IGS)

The electrophoretic pattern in cellulose acetate showed a band in the IgG region, which was confirmed on isoelectric focusing but it was not possible to determine whether this band was 7S IgM or IgG. Otherwise serum Igs were within normal limits.

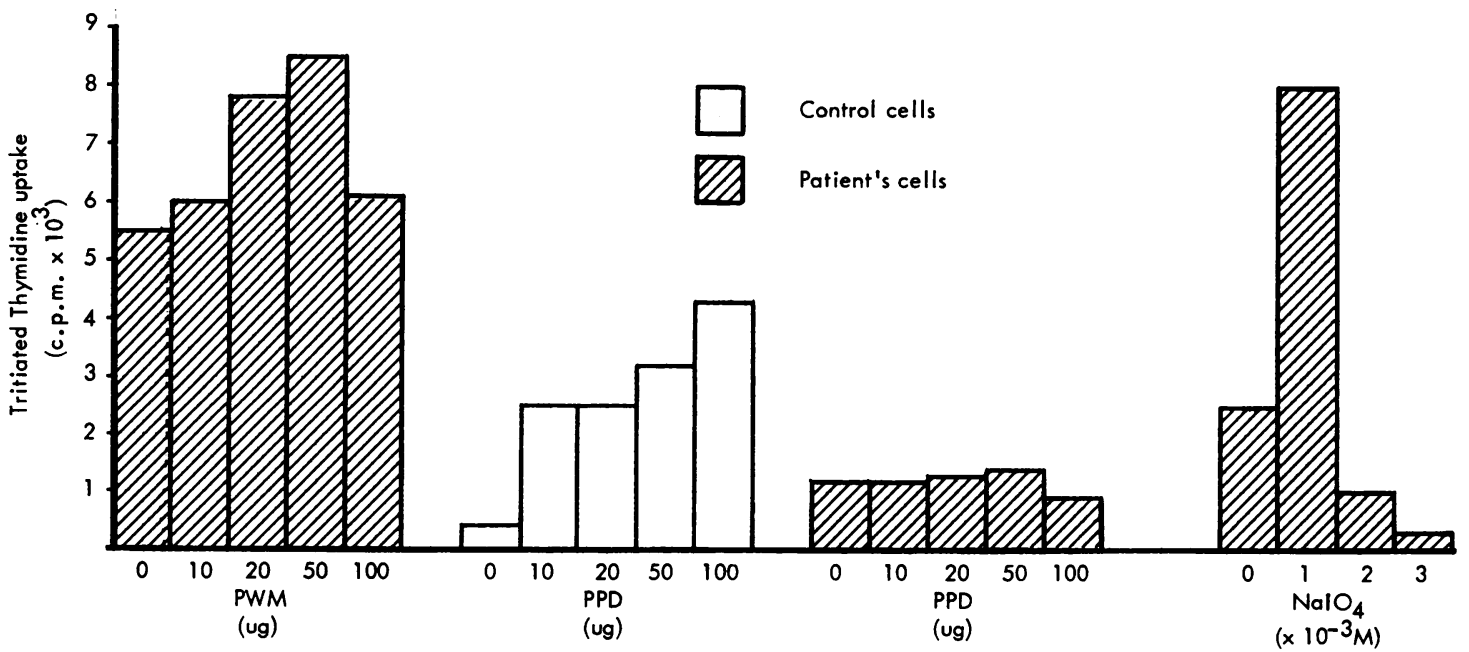

Fig 5 Response to $P W M, P P D$, and $\mathrm{NalO}_{4}$ (tritiated thymidine uptake). 


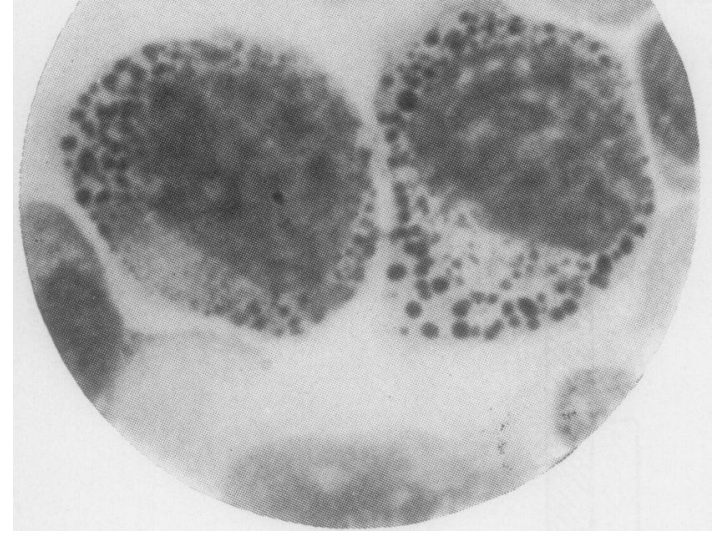

Fig 6 Two leukaemic cells stained by the PAS reaction, showing positive cytoplasmic granules.

\section{Discussion}

The high spontaneous rosette count together with the high peripheral white cell count suggests a marked proliferation of $T$ cells. The lack of surface Ig, $C_{3}$, and aggregate receptors-recognized B cell markers-support this. Furthermore $92 \%$ of the cells were stained by human anti-T cell serum after the addition of appropriate conjugate, and pretreatment with the same serum produced marked inhibition of rosette formation.

The lack of staining by anti T- or B-blast serum indicates that the cells were relatively mature although morphologically by both light microscopy and electron microscopy they were abnormal.

Dr M. F. Greaves also kindly tested a sample of these leukaemic cells for $B$ and $T$ cell surface markers and found a complete absence of $B$ markers. He confirmed the high SRFC rosette incidence, but with antihuman brain serum (for specificity see Greaves, Janossy, and Doenhoff, 1974) obtained no membrane staining, although with rabbit anti-T blast serum he found positive staining, in contrast to the anti-T blast result we obtained. It is possible that these two anti-T blast sera may have specificities for different antigenic phases of the T-cell cycle. The negative result with antibrain serum indicates that cells were not in the resting $\left(G_{0}\right)$ phase.

Functionally, the cells could be stimulated by polyclonal mitogens, which indicates that they had not previously undergone blast transformation. The best response was to PHA, generally considered to be a $\mathrm{T}$ cell mitogen (Greaves et al, 1974). The lower response to con A may be due to the fact that this test was performed on cells obtained from the patient three days after cytotoxic treatment had been started, whereas the PHA test was done before.

The cells gave some response to pokeweed mitogen (PWM) and less to endotoxin. Pokeweed mitogen is known to be capable of stimulating both $B$ and $T$ cells in the mouse and in man (Greaves and Janossy, 1972; Greaves et al, 1974). Endotoxin produces practically no stimulation of normal human peripheral lymphocytes (Peavy, Adler, and Smith, 1970). The fact that in the present case it produced some response may be due to the cells not being in the resting phase of the cell cycle, and hence more readily responsive.

Purified protein derivative has been considered a non-specific B cell mitogen in mice not previously immunized (Sultzer and Nilsson, 1972). In the present case, the cells gave no response to doses of 10 to $100 \mu \mathrm{g} / \mathrm{ml}$. In contrast, control normal cells showed up to an eightfold increase in counts over the same dose range.

$\mathrm{NaIO}_{4}$ has been shown to stimulate normal peripheral blood lymphocytes (Parker et al, 1973) but the maximum response of the cells studied here was sharply delimited to a dose of $1 \times 10^{-3} \mathrm{M}$. Further study of dose effects and cell type involved appear to be indicated.

It is unwise to be dogmatic about the selectivity of mitogens for human $T$ and $B$ cell populations, especially when, as in the present case, their effects have not been tested on separated B cells. Nevertheless the results in this case provide some information about the stimulatory properties of these mitogens on a naturally occurring population of almost pure $T$ cells in man.

With regard to the PAS reaction, it has been reported that in mice it is predominantly $T$ lymphoblasts which show positive cytoplasmic granules (Greaves and Janossy, 1972). With the leukaemic cells more than $90 \%$ become PAS positive after PHA stimulation, whereas with normal cells thus stimulated only about $60 \%$ became positive. This suggests that PAS positivity may be a useful histochemical marker for T-blast cells.

Despite their high rate of spontaneous uptake of tritiated thymidine the leukaemic cells were evidently not releasing macrophage inhibition factor, since the patient's serum did not inhibit migration of guinea-pig peritoneal macrophages (test kindly performed by Dr D. Rajapakse).

Classification of lymphoproliferative disorders in man is still based largely on cellular morphology, and conventional haematological data. By the 
application of appropriate tests, lymphocytes in healthy individuals and in patients can now be readily designated as $\mathrm{T}$ - or B-derived cells. It need hardly be pointed out that the application of two reasonably simple tests-for spontaneous sheep cell rosettes and for surface immunoglobulin markersprovides adequate information on which to base decisions about the $\mathbf{T}$ or $\mathbf{B}$ cell origin of leukaemic cells. These tests are becoming increasingly available to large hospital laboratories. Disorders attributable to malignant $\mathbf{B}$ cell proliferation include chronic lymphatic leukaemia (Papamichail et al, 1971; Preud'homme and Seligman, 1972; Grey et al, 1971), Burkitt's lymphoma (Klein, van Furth, Johansson, Emberg, and Clifford, 1972), and other cases of prolymphocytic leukaemic (Catovsky et al, 1973). In the case of prolymphocytic leukaemic investigated here, however, we have been able to assign the leukaemic cells to the $T$ cell category with some certainty, thus adding to the few published case reports of $\mathrm{T}$ cell neoplasms. These include a Sternberg cell sarcoma (Smith, Barker, Clein, and Collins, 1973a), in which, although of T-cell type, the cells were unresponsive to PHA, other T cell leukaemias (Lille, Desplaces, Meens, and Saracino, 1973; Dickler, Siegal, Bentwich, and Kunkel, 1973), and acute lymphoblastic leukaemia (Smith, Terry, Buell, and Sell, 1973b). The monocytoid cell in Sezary's reticulosis is also thought to be T-cell derived (Brouet, Flandrin, and Seligman, 1973), but while the PAS-positive granules in the cytoplasm of Sezary cells are diastase resistant, ie, probably of mucopolysaccharide nature (Taswell and Winkelmann, 1961), in our case the granules behaved like glycogen.

Knowledge of the type of the cell involved should improve understanding of the nature and prognosis of these disorders and might influence clinical management. It appears from the limited number of cases of $T$ cell proliferation reported thus far that the outlook is considerably worse than with B cell disorders, with the notable exception of infectious mononucleosis which is probably a benign, selflimiting instance of $\mathrm{T}$ cell proliferation (Sheldon, Papamichail, Hemsted, and Holborow, 1973).

We thank Miss Diane Sherman for the electron photomicrograph.

\section{References}

Bianco, C., Patrick, R., and Nussenzweig, V. (1970). A population of lymphocytes bearing a membrane receptor for antigen-antibodycomplement complexes. J. exp. Med., 132, 702-720.

Brouet, J. C., Flandrin, C., and Seligman, M. (1973). Thymus-derived nature of the proliferating cells in Sézary's syndrome. New Engl. J. Med., 289, 341-344.
Catovsky, D., Galetto, J., Okos, A., Galton, D. A. G., Wiltshaw, E., and Stathopoulos, G. (1973). Prolymphocytic leukaemia of B and $\mathrm{T}$ cell type. Lancet, 2, 232-234.

Dacie, V. J., and Lewis, M. S. (1963). Practical Haematology. Churchill, London.

Dickler, H. B., and Kunkel, H. G. (1972). Interaction of aggregated $\gamma$-globulin with B lymphocytes. J. exp. Med., 136, 191-196.

Dickler, H. B., Siegal, F. P., Bentwich, Z. H., and Kunkel, H. G. (1973). Lymphocyte binding of aggregated IgG and surface Ig staining in chronic lymphocytic leukemia. Clin. exp. Immunol., 14, 97-106.

Froland, S. S., Natvig, J. B., and Berdal, P. (1971). Surface-bound immunoglobulin as a marker of $B$ lymphocytes in man. Nature [new Biol.], 234, 251-252.

Greaves, M. F., and Janossy, G. (1972). Elicitation of selective T and B lymphocyte responses by cell surface binding ligands. Transplant. Rev., 11, 87-130.

Greaves, M. F., Janossy, G., and Doenhoff, M. (1974). Activation of human $\mathbf{T}$ and $\mathbf{B}$ lymphocytes by polyclonal mitogens. Nature (Lond.), 248, 698-701.

Grey, H. M., Rabellino, E., and Pirofsky, B. (1971). Immunoglobulins on the surface of lymphocytes. IV. Distribution in hypogammaglobulinemia, cellular immune deficiency, and chronic lymphatic leukemia. J. clin. Invest., 50, 2368-2375.

Jondal, M., Holm, G., and Wigzell, H. (1972). Surface markers on human $\mathrm{T}$ and $\mathbf{B}$ lymphocytes. I. A large population of lymphocytes forming nonimmune rosettes with sheep red blood cells. J. exp. Med., 136, 207-215.

Klein, E., van Furth, R., Johansson, B., Ernberg, I., and Clifford, P. (1972). Immunoglobulin synthesis as cellular marker of malignant lymphoid cells, In Oncogenesis and Herpesviruses. Proceedings of a Symposium (International Agency for Research on Cancer, Scientific Publications, no. 2) edited by P. M. Biges, G. de Thé, and L. N. Payne, pp. 253-257. IARC, Lyons.

Lay, W. H., Mendes, N. F., Bianco, C., and Nussenzweig, V. (1971). Binding of sheep red blood cells to a large population of human lymphocytes. Nature (Lond.), 230, 531-532.

Lille, I., Desplaces, A., Meeus, L., and Saracino, R. T. (1973). Thymus-derived proliferating lymphocytes in chronic lymphocytic leukemia. Lancet, 2, 263-264.

Papamichail, M., Brown, J. C., and Holborow, E. J. (1971). Immunoglobulins on the surface of human lymphocytes. Lancet, 2 , 850-852.

Papamichail, M., Keith, H. I., Currey, H. L. F., and Holborow, E. J. (1972). Subpopulations of human peripheral blood lymphocytes distinguished by combined rosette formation and membrane immunofluorescence. Lancet, 2, 64-66.

Parker, J. W., O'Brien, R. L., Steiner, J., and Paolilli, P. (1973). Periodate-induced lymphocyte transformation. II. Character of response and comparison with phytohemagglutinin and pokeweed mitogen stimulation. Exp. Cell Res., 78, 279-286.

Peavy, D. L., Adler, W. H., and Smith, R. T. (1970). The mitogenic effects of endotoxin and staphylococcal enterotoxin $B$ on mouse spleen cells and human peripheral lymphocytes. J. Immunol., 105, 1453-1458.

Preud'homme, J. L., and Seligmann, M. (1972). Surface bound immunoglobulins as a cell marker in human lymphoproliferative diseases. Blood, 40, 777-794.

Sheldon, P. J., Papamichail, M., Hemsted, E. H., and Holborow, E. J. (1973). Thymic origin of atypical lymphoid cells in infectious mononucleosis. Lancet, 1, 1153-1155.

Smith, J. L., Barker, C. R., Clein, G. P., and Collins, R. D. (1973). Characterisation of malignant mediastinal lymphoid neoplasm (Sternberg sarcoma) as thymic in origin. Lancet, 1, 74-77.

Smith, R. W., Terry, W. D., Buell, D. N., and Sell, K. W. (1973). An antigenic marker for human thymic lymphocytes. J. Immunol., 110, 884-887.

Sultzer, B. M., and Nilsson, B. S. (1972). PPD tuberculin-a B-cell mitogen. Nature [new Biol.], 240, 198-200.

Taswell, H. F., and Winkelmann, R. K. (1961). Sézary syndromeA malignant reticulemic erythroderma. J. Amer. med. Ass., 177, 465-472.

Thomas, D. B. (1973). Antibodies specific for human T lymphocytes in cold agglutinin and lymphocytotoxic sera. Europ. J. Immunol., 3, 824-829.

Thomas, D. B., and Phillips, B. (1973). Membrane antigens specific for human lymphoid cells in the dividing phase. J. exp. Med., 138, 64-70. 